\title{
E-STEM project-based learning in teaching science to increase ICT literacy and problem solving
}

\author{
Syarifah Rahmiza Muzana ${ }^{1}$, Jumadi ${ }^{2}$, Insih Wilujeng ${ }^{3}$, Bagus Endri Yanto ${ }^{4}$, Abdul Aziz Mustamin $^{5}$ \\ ${ }^{1,2,3}$ Department of Science Education, Yogyakarta State University, Indonesia \\ ${ }^{4,5}$ Department of Science Education, Institut Agama Islam Negeri Bengkulu, Indonesia
}

\section{Article Info \\ Article history: \\ Received Mar 25, 2021 \\ Revised Aug 24, 2021 \\ Accepted Sep 13, 2021}

\section{Keywords:}

ICT literacy

E-STEM model

Project-based learning

Problem solving

\begin{abstract}
The aim of the research was to determine the effectivity of implementation of e-learning science, technology, engineering, and mathematics (E-STEM) project-based learning model in teaching science to improve information, communication, and technology (ICT) literacy and problem solving. The study adopted quasi-experimental non-equivalent control group design. ESTEM project-based learning model was applied in experimental classroom, while the control classroom applied conventional teaching. The sample was 46 students who was selected using cluster sampling method. They were in grade VIII academic year 2020/2021 which representing the population students of Junior High School 8, in Aceh Besar, Indonesia. The data were collected using test instrument and questionnaires. Validity verification of instrument measured based on Aiken index, while instrument reliability was determined based on Cronbach's alpha coefficient. The data were analyzed using Manova and descriptive quantitative. The result of the study showed that there is meaningful difference of ICT literacy and problem solving mean score based on the difference of both teaching approach. It is concluded that the implementation of E-STEM project-based learning model and problem solving in teaching science has significant impact in increasing ICT literacy and problem solving.
\end{abstract}

This is an open access article under the CC BY-SA license.

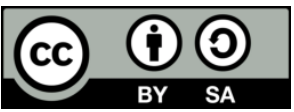

\section{Corresponding Author:}

Syarifah Rahmiza Muzana

Department of Science Education

Yogyakarta State University

Kec. Depok, Kabupaten Sleman, Daerah Istimewa Yogyakarta, Indonesia

Email: syarifahrahmiza.2017@student.uny.ac.id

\section{INTRODUCTION}

The development of knowledge and technology is in line with the improvement of education quality at school, especially in adopting technology. Technology application in teaching simplifies the teaching process and broadens access the unlimited information anywhere anytime. Nowadays, in industry revolution era 4.0, schools are demanded to innovate to deal with the rapid growing technology. Thus, teachers should be able to utilize technology development in teaching to increase students' skill and intelligence [1].

Information, communication, and technology (ICT) literacy ability and problem solving is significant to be acquired by the students in the era of 21 st century. ICT literacy is a 21 st century skill which emphasizes not only on the hardware but also on cognitive skill such as ideas generating and brainstorming, categorizing, conclusion, decision making, and executing the idea to collect the latest information [2]. Meanwhile, problem solving which bases on scientific reasoning ability enables students to answer hypothesis correctly [3]. Therefore, students are acknowledged with 21 st century skill and teaching in order to implement social value professionally. Teachers ought to be trained to foster knowledge and skill 
competence of 21st century on their students [4]. Ahmad, et al. [5] reveal that students are required to be able to apply 21 st century skill actively and learn effectively. Teachers and students, certainly, must be able to utilize technology in teaching process to enhance their literacy [6].

Teaching model is an important component in teaching process [7]. The application of the appropriate model in teaching process plays a role in improving teaching target and it enables to motivate students as well. Selecting the applicable teaching model is important to improve learning result, especially in teaching science. Teaching science needs a real teaching model such a project-based learning. The objective of developing model is to involve students actively during teaching learning process and improve students' understanding by creating, utilizing, choosing a model to describe, explain, predict and control physic phenomenon. Therefore, teachers do not require students to memorize teaching material for their subject but acquiring the needed skill by applying the right teaching model in the classroom.

Considering its important for the students to master the technology, the government has published many policies and regulations to improve teacher's ability to operationalize technology in teaching process, such as conducting trainings for the teacher by using e-learning program. E-learning by utilizing internet is enable teacher and students to conduct teaching learning process despite constrained by space, place and time [8]-[10]. Conducting a teaching using e-learning in science is very helpful. Students are actively involved in the learning process despite of constrained of space, place and time [11]. One of the appropriate approaches in teaching science is using science, technology, engineering and mathematic (STEM). STEM is an approach in which it collaborates four different science subjects; science, technology, engineering and mathematic, as a holistic unit [12], [13].

The objective of STEM in education is in accordance with 21 st century education principle that is enabling the students to acquire science and technology literacy which perceived in reading, writing, observing, conducting and developing an acquired competence to be applied in daily life problem [13], [14]. Every aspect of STEM owns a special characteristic that differentiate among four aspects. Every aspect helps students to solve the problem more comprehensive when they are integrated. The four aspects as elaborated by Kennedy and Odell [15]: i) Science that represents knowledge about laws and concepts of nature; ii) Technology is a skill or a system used to control community, organization, knowledge or to design and utilize an invention to simplify a work; iii) Technique or engineering is a knowledge to operate or to design a procedure to solve a problem; and iv) Mathematic is a knowledge to correlate between amount, number, and space that need logical arguments with or without empirical evidence. All the aspects provide more meaningful knowledge when they are integrated into a teaching learning process.

Implementing the four aspects form a deep understanding towards the learning subject. The characteristic of teaching STEM is an ability of the students to recognize a concept or knowledge of some case [13]. As such in teaching science, STEM helps the students to utilize the technology and to conduct an experiment in order to prove a law or science concept. The benefit of STEM sustainability is better taught early and at the phase when the students are able to combine between cognitive and psychomotor.

Based on the early study using observation, it is obtained that the problem is rooted from some of the following factors. Those are the lack of integrating ICT meaningfully into teaching learning process, students are still unable to operate information and communication technology that helps them get the latest information, besides that in schools they still don't prioritize and facilitate students in terms of mastering ICT Literary but more on knowledge that is traditional learning only, the lack of students' ability on ICT literacy and problem solving, no science teaching approach available which implemented e-learning of science, technology, engineering and mathematics (E-STEM) combined with ICT based on characteristic, aim, material and students learning style. The importance of the problem solving and discovering the concept using teaching model that utilize information technology and to facilitate innovation on the learning source and media is to find the answer from the problem they encounter [16]. Thus, this research aims to solve the teaching problem by applying project-based learning which integrated with E-STEM approach.

A study conducted by Shen, Jiang, and Liu [17] explains that the implementation of STEM approach can be organized using tasks that needs early study on the targeted competence by the students. So that, the combination of integrated STEM subjects is in accordance with the demands of the national curriculum. As supported by previous studies [18]-[20] that teaching learning project-based learning which integrated with STEM is able to improve students' competence. The teaching process that conducted using elearning is able to use multiple digital devices such as smartphone and computer [21].

Data from previous studies revealed that a teaching learning using project-based learning model which integrated with STEM approach is best applied in this study. The use of this model is very helpful for the students to channel their talents and skills [22]. Previous studies [23], [24] found the use of blogging media is not significant in increasing students' ICT literacy. Based on the previous studies, this research is to strengthen previous study's shortcomings, so that the focus is to analyze the implementation of E-STEM project-based learning in teaching science in the classroom to increase ICT literacy and problem solving. 
The E-STEM project-based learning model in teaching science is designed to make teaching learning process more enjoyable. E-STEM project-based learning model contains some teaching steps for students to conduct experiment directly and teaching materials which explain the concept easily. E-STEM learning model is completed with supported elements such as syllabus, lesson plan, students' tasks, and guide book. It is expected to facilitate teacher and students to understand of teaching science in the future. E-STEM project-based learning model in teaching science is designed in accordance with four subjects' science, technology, engineering and mathematic. The use of the model is expected to make the teaching learning process more enjoyable, and able to gain better result in learning. The basic element of this study is the correlation between E-STEM project-based learning model and the increase of ICT literacy and problem solving which shown in Table 1.

Table 1. The correlation between syntax E-STEM project-based learning model

\begin{tabular}{|c|c|c|c|}
\hline No & $\begin{array}{l}\text { Syntax E-STEM project- } \\
\text { based learning model }\end{array}$ & Problem solving indicators & ICT literacy indicators \\
\hline 1. & $\begin{array}{l}\text { Questioning about daily } \\
\text { physic phenomenon. }\end{array}$ & $\begin{array}{l}\text { Reflection; identifying a problem; formulating } \\
\text { the problem }\end{array}$ & $\begin{array}{l}\text { Knowing how to use the } \\
\text { computer/internet; looking up for } \\
\text { information }\end{array}$ \\
\hline 2. & Arranging project plan & $\begin{array}{l}\text { Brainstorming; Selecting a relevant material; } \\
\text { Selecting the right strategy to solve the problem }\end{array}$ & $\begin{array}{l}\text { Obtaining the information; comparing the } \\
\text { information }\end{array}$ \\
\hline 3. & Learning independently & $\begin{array}{l}\text { Selecting relevant materials; Doing some } \\
\text { activities in problem solving }\end{array}$ & $\begin{array}{l}\text { Managing the information; Obtain the } \\
\text { accurate information; Obtain relevant } \\
\text { information }\end{array}$ \\
\hline 4. & $\begin{array}{l}\text { Designing and } \\
\text { collaborating between } \\
\text { subjects }\end{array}$ & $\begin{array}{l}\text { Selecting the right strategy to solve the } \\
\text { problem; Doing activities in solving the } \\
\text { problem; Identifying the tool and materials in } \\
\text { problem solving }\end{array}$ & $\begin{array}{l}\text { Designing project based on the available } \\
\text { information; Designing and creating } \\
\text { efficient information in digital } \\
\text { environment }\end{array}$ \\
\hline 5. & Evaluating & $\begin{array}{l}\text { Presenting the answer; Presenting the reason; } \\
\text { Doing reflection }\end{array}$ & $\begin{array}{l}\text { Disseminating the information; Presenting } \\
\text { the relevant information }\end{array}$ \\
\hline 6. & Scoring & Presenting the answer/result; doing reflection & $\begin{array}{l}\text { Doing evaluation toward the quality } \\
\text { information obtained }\end{array}$ \\
\hline
\end{tabular}

Dealing with the background and the problems, this study focused on the implementation of a ESTEM project-based learning model in teaching science. It aims to increase ICT literacy and problem solving. The results of this study can contribute to teachers in varying good learning models and media in schools so that they can improve student learning outcomes. Through the implementation of e-STEM projectbased learning model in teaching science, teacher understands science contents and understands how to teach various concepts with the application of technology. Thus, the question of this research is how effective the implementation of E-STEM project-based learning model in teaching science to increase ICT literacy and problem solving?

\section{RESEARCH METHOD}

\subsection{Research design}

This study aimed to find out the impact of E-STEM model implementation project-based learning in teaching science to increase ICT literacy and problem solving. The research is using design quasi-experiment non-equivalent control group to compare the improvement of ICT literacy and problem solving between experimental and control classroom. For experimental classroom was given treatment by using E-STEM project-based learning model, while for control classroom was given treatment by applying conventional teaching. This study was conducted in three months, started on May to July 2020. The application of ESTEM project-based learning model has syntax or steps in teaching activity. This syntax was designed based on correlation between syntax project-based learning model, the characteristic of STEM approach and characteristic of e-learning. Procedure syntax E-STEM project-based learning model is shown in Table 2. 
Table 2. Teacher and student activities based on syntax E-STEM project-based learning

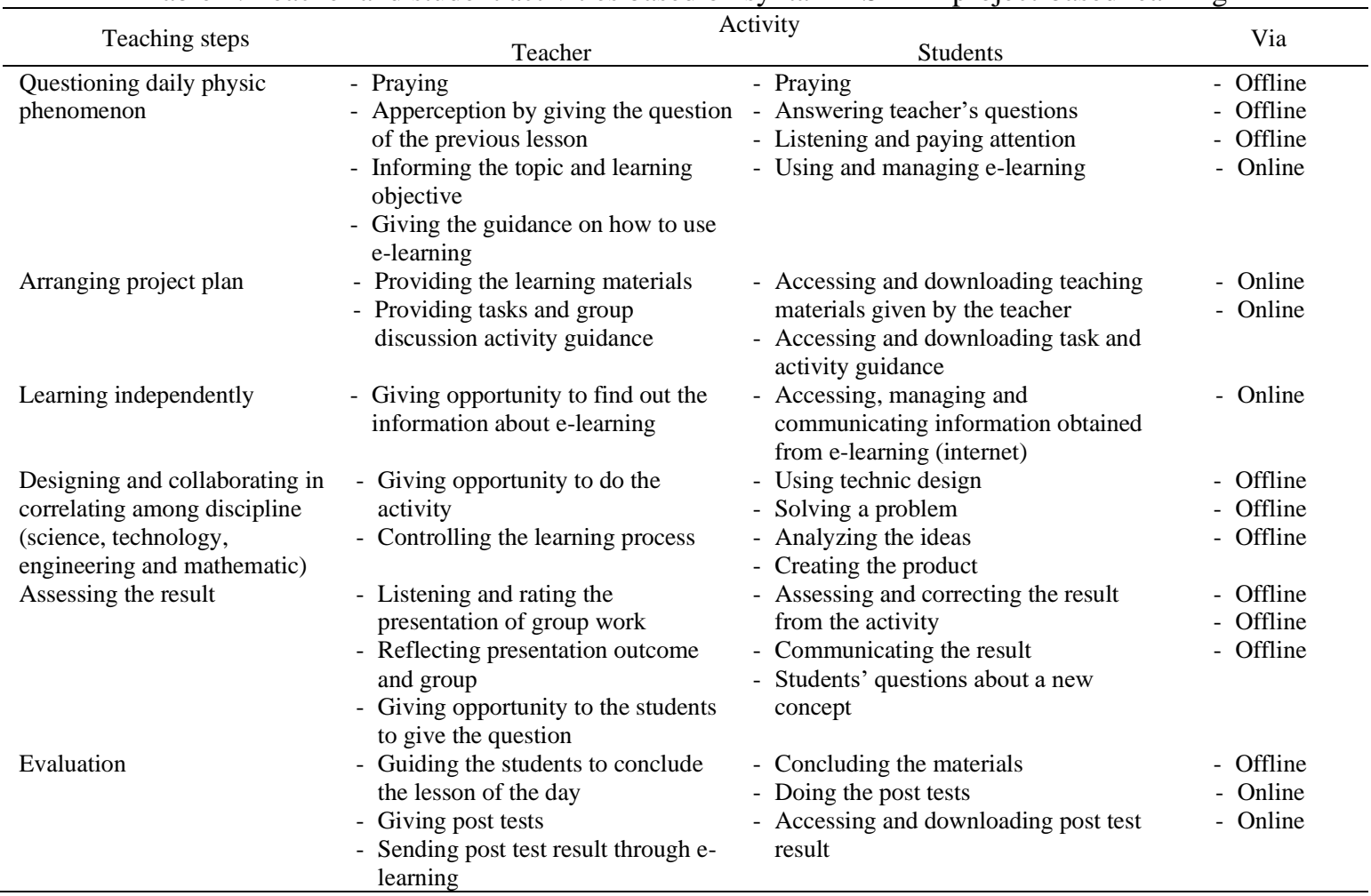

\subsection{Sample}

Cluster sampling is adopted as the technique is selecting population and sample for this research. Junior High School students are the population of the study. They are from students of year VIII MTs N in Aceh Besar, Indonesia. 95 students are considered as population of the study, but only 46 students of year VIII are taken as the sample study. There were 23 students for every experimental group and 23 students for control group. Because the sample members of the population are very large, the sampling is based on predetermined groups [25]. The sample in this research is teacher and students of year VIII MTs N in Aceh Besar. The location is chosen based on the better means in the school such as Wi-Fi, and smartphone. So, the teaching learning process using E-STEM project-based learning is easy to execute.

\subsection{Instrument and data analysis}

Data collection was conducted using test instrument and questionnaire. ICT literacy ability questionnaire was aimed to find out how far the students understand and use technology information in teaching learning process. The questionnaires were distributed to the students to get to know students' ICT literacy ability. While, the test instrument was used to measure students' ability in problem solving. Test instrument to know the student ability in problem solving was aimed to find out students' ability in problem solving during learning process by solving essay question. This kind of questions was built based on indicators for every component with scoring scale $0-3$, for scoring scale category is 0 score (no answer), 1 (when correct answer only one step), score 2 (when correct answer only two steps), and score 3 (when correct answer in every step). This test is given to the students before teaching process (pretest) and after teaching process (posttest). The instrument outline used to find out ICT literacy ability is shown in Table 3 and test instrument of problem solving shown in Table 4.

The research instrument is valid since it is validated by four education experts. Validity analyzing was used to know the validity of the instrument items. Instrument validity verification was conducted based on Aiken index (V). The measuring result is shown in Table 5. Instrument reliability is determined based on Coefficient Cronbach's alpha. Test instrument reliability of problem solving is 0.92 , when questionnaire instrument ability of ICT literacy 0.95 , thus instrument reliability score has high category [26]. The result of the study was analyzed using descriptive quantitative using SPSS for Windows version 22. To find out the data normality was using one-sample test and to check homogeneity was done by Levine test. Then, Manova test was conducted to identify significant difference in mean score from experimental classroom and control classroom. 
Table 3. Instrument outline of ICT literacy ability

\begin{tabular}{ll}
\hline \multicolumn{1}{c}{ Aspect } & \multicolumn{1}{c}{ Indicators } \\
\hline Access & Know how to use, find and get information and obtained needed information. \\
Manage & Apply organization in managing and designing new but incomplete information in order to be re classified. \\
Integrate & Interpret, conclude, compare information and distinguish the information using computer devices \\
Evaluate & $\begin{array}{l}\text { Assess the quality of information, relevance, suitability, adequacy of information, and efficiency of new } \\
\text { information with the right source. }\end{array}$ \\
Create/design & $\begin{array}{l}\text { Obtaining accurate information by adapting, applying, designing and creating information in digital community. } \\
\text { Communicate }\end{array}$ \\
& $\begin{array}{l}\text { Presenting relevant information, publishing, distributing information which beneficial for the community using } \\
\text { effective digital media. }\end{array}$ \\
\hline
\end{tabular}

Table 4. The instrument outline for the problem-solving ability

\begin{tabular}{|c|c|}
\hline Aspect & Indicator \\
\hline \multirow[t]{2}{*}{ Identify a problem } & Identify the problem in teaching science \\
\hline & Formulate the problem in question form \\
\hline \multirow{7}{*}{$\begin{array}{l}\text { Design and make a plan of } \\
\text { problem solving }\end{array}$} & Do the brainstorming \\
\hline & Choose the right materials to the question \\
\hline & Choose the right strategy to solve the problem \\
\hline & Identify tools and materials in solving the problem \\
\hline & Do some activities in solving the problem of teaching science \\
\hline & Present the answer \\
\hline & Present the reason \\
\hline \multirow[t]{2}{*}{ Evaluate the problem } & Formulate the conclusion \\
\hline & Do reflection \\
\hline
\end{tabular}

Table 5. Result of coefficient indexes Aiken instrument validity

\begin{tabular}{ccc}
\hline Instrument & $\mathrm{V}$ & Explanation \\
\hline ICT literacy questionnaire & 0.76 & Valid \\
Test problem solving assessment & 0.79 & Valid \\
\hline
\end{tabular}

\section{RESULTS AND DISCUSSION}

The effectivity achievement of e-learning of science, technology, engineering and mathematics E-STEM project-based learning model was determined based on the impact of ICT literacy ability and problem solving. The application of E-STEM project-based learning model is effective when it is able to increase ICT literacy ability and problem solving. Early test result, normality test and homogeneity test. Significant normality score was determined based on Kolmogorov-Smirnov. For normality test score in experimental classroom is 0.151 , control classroom is 0.122 . Both significancy scores is higher than 0.05. Thus, it means that the data is normally distributed. Homogeneity test result for ICT literacy ability and problem solving revealed the significancy score of 0.219 and 0.389 . It means that data from population has homogeneity variants. The effectivity of E-STEM teaching model based on problem solving result seen from analysis result at score diversity normality gains and Manova test. The result of problem solving ability using E-STEM project-based learning model in teaching science can be seen in Table 6.

Table 6 indicates that $\mathrm{N}$-gain score for experimental classroom is 58.48 or $58 \%$ which means effective. Meanwhile, $\mathrm{N}$-gain score for control classroom is $41.56 \%$ or $42 \%$ which means less effective. It can be concluded that the application of E-STEM project-based learning model in teaching science is effective to increase problem solving ability of junior high school students. After N-Gain score obtained, the next step is to test the hypotheses using Manova with SPSS program support. For trust degree 95\%, if Sig. Manova score $<0.05$, it can be concluded that there is meaningful difference of mean ICT literacy score and problem solving based on two different teaching models. Then, Benferoni test was conducted, the starred data shows which treatment indicates the difference between ICT literacy mean score and problem solving Manova test. The result can be seen in Table 7 .

Table 6. Data analysis score N-gain on students' problem-solving ability

\begin{tabular}{ccc}
\hline Data & Experimental classroom & Control classroom \\
\hline Student & 23 & 23 \\
Mean & 58.48 & 41.56 \\
Std. deviation & 14.06 & 12.38 \\
Minimum & 25.00 & 20.00 \\
Maximum & 81.82 & 66.67 \\
Criteria & Effective & Less effective \\
\hline
\end{tabular}


Table 7. Tests of between-subjects effects

\begin{tabular}{ccccccc}
\hline Source & Dependent variable & Type III sum of Squares & Df & Mean Square & F & Sig. \\
\hline Corrected model & ICT literacy & $418.791^{\mathrm{a}}$ & 1 & 418.791 & 118.009 & .000 \\
& Problem solving & $1539.103^{\mathrm{b}}$ & 1 & 1539.103 & 70.172 & .000 \\
Intercept & ICT literacy & 5359.791 & 1 & 5359.791 & 1510.311 & .000 \\
& Problem solving & 303425.641 & 1 & 303425.641 & 13833.996 & .000 \\
Group & ICT literacy & 418.791 & 1 & 418.791 & 118.009 & .000 \\
& Problem solving & 1539.103 & 1 & 1539.103 & 70.172 & .000 \\
\hline
\end{tabular}

Table 8 indicates that significant score $<0.05$. It means $\mathrm{H}_{0}$ is declined, it can be concluded that there is significant difference in problem solving ability and ICT literacy ability between experimental classroom and control classroom. There is a meaningful difference ICT literacy mean score based on two different teaching models. Based on Benferoni test, ICT literacy model mean score difference is E-STEM learning model in experimental classroom and conventional model in control classroom. For the problem-solving ability, there is meaningful difference at the mean score based on different teaching model. It can be concluded that E-STEM teaching model for experimental classroom is more effective in increasing ICT literacy and problem-solving ability than conventional model at control classroom.

Table 8. Pairwise comparisons

\begin{tabular}{lllccccc}
\hline $\begin{array}{c}\text { Dependent } \\
\text { variable }\end{array}$ & (I) Group & (J) Group & $\begin{array}{c}\text { Mean difference } \\
(\mathrm{I}-\mathrm{J})\end{array}$ & Std. Error & Sig. & $\begin{array}{c}\text { 95\% Confidence interval for difference } \\
\text { Lower bound }\end{array}$ & Upper bound \\
\hline ICT literacy & Control & Experiment & $-5.680^{*}$ & .523 & .000 & -6.730 & -4.630 \\
& Experiment & Control & $5.680^{*}$ & .523 & .000 & 4.630 & 6.730 \\
Problem & Control & Experiment & $-10.889^{*}$ & 1.300 & .000 & -13.500 & -8.278 \\
solving & Experiment & Control & $10.889^{*}$ & 1.300 & .000 & 8.278 & 13.500 \\
\hline
\end{tabular}

The research found that by applying technology of E-STEM project-based learning model become an effective and efficient tool to be used as a modality in teaching. As the result, there is a meaningful difference of mean score of ICT literacy and problem solving based on the difference between the two models applied. The findings reveal that there is an achievement related to effectivity of the E-STEM projectbased learning model of ICT literacy. This is because teaching E-STEM learning model applies e-learning principles that is relevant with previous study [27], that e-learning is the use of computer and internet which presented various solution in teaching. According to Darmawan [9], e-learning is an internet application that can connect between teacher and students in an online classroom. E-learning was created to solve the challenge between teacher and students, especially for time, space and place flexibility.

Based on the findings, E-STEM project-based learning application is able to increase ICT literacy and students' problem solving. It supports students to be involved in experienced of using smartphone, sending message, and using internet. Thus, it is very helpful in increasing the learning with e-learning. It is supported by study of Eliana, et al. [28], it found that the use of e-learning in teaching to increase the efficiency, effectivity and accountability in teaching. Teaching with e-learning ease the teacher to directly assess and measure the effectivity of teaching, so it is easy to control the activities students are doing. Social media and various online communication apps make it possible for the students to connect and discuss about lesson. In e-learning, everything is fast, the availability of technology to create an interesting course, mobile and course contents must be recycled to give the student the latest information. Khan and Khader [29] stated that e-learning not only change the way teacher give instruction to the students but also change the education paradigm for the students to get involved with teaching materials and the way to gather new information.

E-learning in this study used WhatsApp media through WhatsApp Group (WAG). This application can help teacher to communicate and collaborate with students in an online platform in providing content, learning task and showing the students result without going face to face in the classroom. WAG is similar to Facebook which is very easy to use by the students, but WAG is better in providing group facility that enables students and teacher to communicate. This platform creates possibility for teacher and students to communicate through chat. It serves opportunity for the students to communicate and collaborate in virtual classroom. WhatsApp leads to exploration of communication forms between teacher and students and teacher role to create a constructive learning virtual classroom [30].

The use of WAG in teaching process is very effective because this application has some advantages. Free messaging, picture, video and audio note posting and location sharing are some of WAG services. Those features offer students to express their feeling, thoughts and ideas or incidents better, easier and more efficient. WhatsApp is mobile phone and web-based application which integrated with various application used to communicate with other user, from education, business, entertainment. The application keeps

E-STEM project-based learning in teaching science to increase ICT literacy ... (Syarifah Rahmiza Muzana) 
developing and expected the function of the application not only for chatting and broadcast but also to collaboration applications and information sharing. Thus, the objective of e-learning can be achieved [31].

The use of WhatsApp Messenger mobile learning which integrated group investigated method is effective to be applied in teaching process in order to increase critical thinking of the students. The teaching design involves introducing, grouping, planning, presenting, organizing, investigating, evaluating, and closing. Thinking ability independently and critically is trained through investigating a problem in a group as a whole, students are interested and motivated to follow the teaching using WhatsApp combined with investigation method [32]. The study conducted by Susilowati [33] explains the online teaching process using WhatsApp group is effective in increasing the students' independence. There are some strengths that cause this teaching mode effective, that because the students are very familiar in using WhatsApp group, and teaching model applied in the online teaching trough WhatsApp group media motivate students to participate actively. Moreover, students are easy to get information such as learning materials, photo, tests question, lecturer explanation through chat or voice note. Students do not need to write down the materials given. The discussion is active, because lecturer provide feedback, questions and answer. Finally, the students are easy to understand the materials given.

Dealing with the findings, the E-STEM project-based learning model in experimental classroom is more effective to increase ICT literacy and problem solving ability than conventional model in control classroom. For there is a superiority of E-STEM project-based learning model from conventional teaching approach. According to Becker and Park [34], there some advantages of STEM approach: i) The implementation of STEM approach shows the positive effect towards students in science subject; ii) STEM approach teaches students to solve the problem by thinking creatively and leading students to be creative; iii) With technology, students are able to apply their understanding in knowledge, Mathematic and technology and increase the connection from those understanding; iv) STEM approach bridge an abstract concept into mathematic to be used in science, technology and technic; v) The teaching is based on constructivism theory that can make students getting the understanding better when they are actively build their own understanding by working and applying the ideas to solve the problems [35]. It is supported by previous research [36], [37] interdisciplinary learning approach for students contextually with STEM education. Robinson [38] concludes that project-based learning is an effective approach to involve the students in real work. The approach also broadens students' knowledge and skills they had. Thus, the school curriculum needs to be integrated with STEM learning through government policies [39], [40].

\section{CONCLUSION}

It can be concluded that the e-learning of science, technology, engineering and mathematics (ESTEM) project-based learning model is an effective tool to be used as a modality in teaching. There is meaningful difference of Information, communication, and technology (ICT) literacy mean score and problem solving based on two different models applied. The implementation of E-STEM project-based learning model in experimental classroom is more effective to increase ICT literacy and problem-solving ability that conventional model in control classroom. E-STEM project-based learning model taught students to solve the problem by critical thinking, creative, and able to increase understanding towards integrated science, technology, engineering and mathematic.

This study can be used as a reference for teachers who had training about E-STEM to be applied in teaching. Moreover, teacher should provide online learning media that can be accessed by the student freely so that students are not difficult in using an online course. Recommendations of this study provide empirical information for teachers to be easy in explaining the lesson to the students. Besides that, students are able to perform tasks by applying the E-STEM project-based model learning in teaching science independently and effectively.

\section{ACKNOWLEDGEMENTS}

This research was supported by the Ministry of Finance and Research and Technology of Higher Education through Doctoral Grant Program 2021.

\section{REFERENCES}

[1] A. Hermino and I. Arifin, "Contextual Character Education for Students in the Senior High School," European Journal of Educational Research, vol. 9, no. 3, pp. 1009-1023, 2020, doi: 10.12973/eu-jer.9.3.1009.

[2] B. Joyce, M. Weil, and E. Calhoun, Models of Teaching. USA: Pearson Education Inc, 2009. 
[3] B. E. Yanto, B. Subali, and S. Suyanto, "Improving Students' Scientific Reasoning Skills through the Three Levels of Inquiry," International Journal of Instruction, vol. 12, no. 4, pp. 689-704, 2019.

[4] C. Tican, and S. Deniz, "Pre-service Teachers' Opinions about the use of 21st Century Learner and 21st Century Teacher Skills," European Journal of Educational Research, vol. 8, no. 1, pp. 181-197, 2019, doi: 10.12973/eujer.8.1.181.

[5] M. Ahmad, J. Badusah, A.Z. Mansor, A. Abdul Karim, F. Khalid, M.Y. Daud, R. Din, and D.F. Zulkefle, "The Application of 21st Century ICT Literacy Model among Teacher Trainees," Turkish Online Journal of Educational Technology-TOJET, vol. 15, no. 3, pp. 151-161, 2016.

[6] O. Celik, H. Çokçalişkan, and A. Yorulmaz, "Investigation of the Effect of Pre-Service Classroom Teachers' Critical Thinking Disposition on Media Literacy," International Journal of Evaluation and Research in Education (IJERE), vol. 7, no. 3, pp. 194-202, 2018, doi: 10.11591/ijere.v7i3.13960.

[7] A. Arsyad, Learning Media, (in Indonesia). Jakarta: Raja Grafindo Persada, 2016.

[8] M. Aparicio, F. Bacao and T. Oliveira, "An E-learning Theoretical Framework," Educational Technology and Society, vol. 19, no. 1, pp. 292-307, 2016.

[9] D. Darmawan, The Development of E-learning Theory and Design, (in Indonesia). Bandung: Remaja Rosdakarya, 2016.

[10] D. Singhal, "Understanding Student-Centered Learning and Philosophies of Teaching Practices," International Journal of Scientific Research \& Management, vol. 5, no. 2, pp. 5123-5129, 2017.

[11] I. K. Suartama, et al., "Development of E-Learning oriented Inquiry Learning based on Character Education in Multimedia Course," European Journal of Educational Research, vol. 9, no. 4, pp. 1591-1603, 2020, doi: 10.12973/eu-jer.9.4.1591.

[12] A. Roberts, "A Justification for STEM Education," Technology and Engineering Teacher, vol. 71, no. 8, pp. 1-4, 2012.

[13] R.W. Bybee, The Case for STEM Education: Challenges and Opportunity. Arlington, VI: National Science Teachers Association (NSTA) Press, 2013.

[14] National Governor Association (NGA), Building a Science, Technology, Engineering and Math Agenda. Washington, D.C: NGA Center, 2011.

[15] T. Kennedy and M. Odell, "Engaging Students in STEM Education," Science Education International, vol. 25, no. 3, pp. 246-258, 2014.

[16] R. Perdana, A. Wahyu, and H. Kuswanto, "Simulation using VBA in Microsoft Excel to Enhance Pre-service Physics Teachers' Motivation," International Journal of Science and Business, vol. 3, no. 3, pp. 114-123, 2019, doi: 10.5281/zenodo.2649953.

[17] J. Shen, S. Jiang, and O.L. Liu, "Reconceptualizing a College Science Learning Experience in the New Digital Era: A Review of Literature," in Emerging Technologies for STEAM Education. Educational Communications and Technology: Issues and Innovations. Springer, Cham, 2015, pp. 61-79.

[18] J. Afriana, A. Permanasari, and A. Fitriani, "Implementation Project-Based Learning Integrated STEM to Improve Scientific Literacy Based on Gender," (in Indonesia), Jurnal Inovasi Pendidikan IPA, vol. 2, no. 2, pp. 202-212, 2016, doi: 10.21831/jipi.v2i2.8561.

[19] I. W. Santyasa, N. K. Rapi, and I. Sara, "Project based Learning and Academic Procrastination of Students in Learning Physics," International Journal of Instruction, vol. 13, no. 1, pp. 489-508, 2020, doi: 10.29333/iji.2020.13132a.

[20] M.T. Hora and A.K. Oleson, "Examining Study Habits in Undergraduate STEM Courses from a Situative Perspective," International Journal of STEM Education, vol. 4, no. 1, pp. 1-19, 2017, doi: 10.1186/s40594-0170055-6.

[21] G.Z. Liu and G.J. Hwang, "A Key Step to Understanding Paradigm Shifts in E-learning: Towards Context-Aware Ubiquitous Learning," British Journal of Educational Technology, vol. 41, no. 2, pp. E1-E9, 2010, doi: 10.1111/j.1467-8535.2009.00976.x.

[22] D.A. Sudjimat, "Implementation of Project based Learning Model in Mechanical Machining Skills Package of Vocational High School," AIP Conference Proceedings, Vol. 1778, no. 1, 2016, doi: 10.1063/1.4965758.

[23] M. Papastergiou, V. Gerodimos, and P. Antoniou," Multimedia blogging in physical education: Effects on student knowledge and ICT self-efficacy," Computers \& Education, vol. 57, no. 3, pp. 1998-2010, 2011, doi: 10.1016/j.compedu.2011.05.006.

[24] K. Ostler, "Century STEM Education: A Tactical Model for Long Range Success," International Journal of Applied Science and Technology, vol. 2, no. 1, pp. 15-17, 2012.

[25] Sugiyono, Educational Research Methods, (in Indonesia). Bandung: Alfabeta, 2015.

[26] K.S. Taber, "The use of Cronbach's Alpha when Developing and Reporting Research Instruments in Science Education," Research in Science Education, vol. 48, no. 6, pp. 1273-1296, 2018.

[27] C.M. Hung, G.J. Hwang, and I. Huang, "A project-based digital storytelling approach for improving students' learning motivation, problem-solving competence and learning achievement," Educational Technology \& Society, vol. 15 , no. 4, pp. 368-379, 2012.

[28] E.D.S. Eliana, S. Senam, I. Wilujeng, and J. Jumadi, "The Effectiveness of Project-based E-Learning to Improve ICT Literacy," Jurnal Pendidikan IPA Indonesia, vol. 5, no. 1, pp.51-55, 2016.

[29] A.A Khan and S.A. Khader, "An approach for Externalization of Expert Tacit Knowledge using a Query Management System in an E-Learning Environment," International Review of Research in Open and Distributed Learning, vol. 15, no. 6, pp. 257-274, 2014. 
[30] H. R. Robles, J. Guerrero, H. Linas, and P. Montero, "Online Teacher-Students Interactions using WhatsApp in a Law Course," Journal of Information Technology Education: Research, vol. 18, pp. 231-252, 2019, doi: $10.28945 / 4321$.

[31] A. Prajana, "Utilization of the WhatsApp for Learning Media in UIN Ar-Raniry Banda Aceh," (in Indonesia), Cyberspace: Jurnal Pendidikan Teknologi Informasi, vol. 1, no. 2, pp.122-133, 2017, doi: 10.22373/cs.v1i2.1980.

[32] S. Kartikawati and H. Pratama, "The Effect of Using WhatsApp Messenger as an Integrated Mobile Learning Group Investigation Method on Critical Thinking Ability," (in Indonesia), Jurnal Pendidikan Teknik Elektro, vol. 2, no. 2, pp.33-38, 2017, doi: 10.25273/jupiter.v2i2.1797.

[33] E. Susilowati, "How is the online learning in the middle of COVID-19 pandemic through WhatsApp gropu?" (in Indonesia), Jurnal Pendidikan Matematika Raflesia, vol. 5, no. 3, pp.1-25, 2020, doi: 10.33449/jpmr.v5i3.12896.

[34] K.H. Becker and K. Park, "Integrative Approaches among Science, Technology, Engineering, and Mathematics (STEM) Subjects on Students' Learning: A Meta-Analysis," Journal of STEM Education: Innovations and Research, vol. 12, no. 5-6, pp. 23-37, 2011.

[35] J. S. Krajcik, C.M. Czerniak, and C.F. Berger, Teaching Science in Elementary and Middle School Classrooms: A Project-Based Approach, 2nd ed. New York: McGraw Hill, 2002.

[36] T. Mujtaba, R. Sheldrake, M. J. Reiss, and S. Simon, "Students' science attitudes, beliefs, and context: Associations with science and chemistry aspirations," International Journal of Science Education, vol. 40, no. 6, pp, 644-667, 2018.

[37] A. T. Twiningsih, "Improving Student Learning Outcomes through Stem-based Magic Box Medium in the Concept of Addition Theory," International Journal of Research in STEM Education (IJRSE), vol. 2, no. 1, pp. 79-90, 2020, doi: 10.31098/ijrse.v2i1.183.

[38] J.K. Robinson, "Project-based learning: Improving student engagement and performance in the laboratory," Anal. Bioanal. Chem., vol. 405, no. 1, pp. 7-13, 2013.

[39] H. B. Gonzalez and J. J. Kuenzi, Science, Technology, Engineering, and Mathematics (STEM) Education: A Primer. Library of Congress. Congressional Research Service, 2012.

[40] N. Khaeroningtyas, A. Permanasari, and I. Hamidah, "STEM learning in material of temperature and its change to improve scientific literacy of junior high school students," Jurnal Pendidikan IPA Indonesia, vol. 5, no. 1, pp. 94-100, 2016. 